Article

\title{
Who Goes to College via Access Routes? A Comparative Study of Widening Participation Admission in Selective Universities in Ireland and England
}

\author{
Katriona O'Sullivan ${ }^{1}$, Delma Byrne ${ }^{2, *}$, James Robson ${ }^{3}$ and Niall Winters ${ }^{3}$ \\ ${ }^{1}$ Department of Adult and Community Education, Maynooth University, Co Kildare, Ireland; \\ E-Mail: katriona.osullivan@mu.ie \\ 2 Department of Sociology, Maynooth University, Co Kildare, Ireland; E-Mail: delma.byrne@mu.ie \\ ${ }^{3}$ Department of Education, University of Oxford, Oxford, OX2 6PY, UK; E-Mails: james.robson@education.ox.ac.uk (J.R.), \\ niall.winters@education.ox.ac.uk (N.W.) \\ * Corresponding author
}

Submitted: 28 June 2018 | Accepted: 18 October 2018 | Published: 10 January 2019

\begin{abstract}
This article explores changing national widening participation (WP) policy and responses from Higher Education institutions (HEls) from a cross-national perspective. Specifically, the use of contextualised admissions and the provision of foundation year programmes in selective universities in Ireland and England are the key foci of interest. Using data gathered from WP students in two selective universities in Ireland and England, we explore how student characteristics differ according to the WP route undertaken. In an attempt to generate more knowledge of how HEls enact WP policy, we draw on interviews conducted with staff involved in admission decision-making to explore how those with responsibility for admission within each institutional context perceive the WP pathways and their aims. The findings highlight how important it is for selective universities to adopt multiple WP pathways given that the use of contextualised admission and the provision of foundation years attract quite diverse student intakes. In both contexts, those entering through foundation years have experienced greater levels of disadvantage in terms of family history of education and family occupation compared to their contextualised admission counterparts. The qualitative findings reveal that those with responsibility for admission perceive the WP admission routes in different ways, highlighting a clash between institutional culture and the goals of WP.
\end{abstract}

\section{Keywords}

access; England; higher education admission; Ireland; selective universities; social class; widening participation

\section{Issue}

This article is part of the issue "Inequalities in Access to Higher Education: Methodological and Theoretical Issues", edited by Gaële Goastellec (University of Lausanne, Switzerland) and Jussi Välimaa (University of Jyväskylä, Finland).

(C) 2019 by the authors; licensee Cogitatio (Lisbon, Portugal). This article is licensed under a Creative Commons Attribution 4.0 International License (CC BY).

\section{Introduction}

National policy responses to Widening Participation (WP) have varied over time and place, and as a result, changes have occurred to WP admission routes within Higher Education Institutions (HEIs). Yet, despite the voluminous literature pertaining to WP initiatives, there is a dearth of cross-national empirical research that seeks to capture commonalities and differences in the interpretation of WP policy responses (Clancy \& Goastellec, 2007). This article addresses this gap and examines current na- tional (country level) and institutional (within HEIs) WP policy from a comparative perspective, placing emphasis on how WP policy has shaped admission routes to two selective universities in the Republic of Ireland and England. Specifically, the use of contextualised admissions and the provision of foundation year programmes in two selective universities are the key foci of interest. By 'selective university' we mean a university in which the number of applicants far exceeds the number of available positions, thus allowing the university to exercise some discretion in the admission process (Ehrenberg \& Sherman, 1984). 
Using data gathered from WP students in two selective universities in Ireland and England, we explore how student intakes differ according to the WP admission route undertaken. We then use data gathered from university staff members with responsibility for admissions to illustrate commonalities and differences in how WP policy is enacted in each setting. The key research questions addressed are: (1) Do the characteristics of students entering selective universities differ depending on the WP admission route taken? That is, do the characteristics of WP students entering through a foundation year differ from those entering directly through contextualised admissions? (2) How are the WP admission routes and their aims interpreted by those with responsibility for admissions? How are the rules interpreted?

In the next section, we provide a rationale for a crossnational study, and draw on the existing empirical and theoretical literature that highlights the socially stratified nature of HE admission systems. Section 3 provides an overview of WP policy developments pertaining to Ireland and England. The methodological approach to the interviews which sought to explore decision-makers experiences' and reflections on the admission process is set out in Section 4; and Section 5 offers a cross-national comparative analysis of the characteristics of students who have gained admission to HE through foundation year programmes and contextualised admission routes. The qualitative findings report on three themes that emerged during the analyses: (1) how those with responsibility for admissions understand the dynamics of processes of inequality in educational attainment; (2) how those with responsibility for admissions make distinctions between each of the WP routes; and (3) how WP initiatives are located within the context of the selective universities. The article concludes with a summary and discussion of how WP initiatives are positioned in the broader admissions processes in selective universities.

\section{Rationale and Review of Literature on Higher Education Admission Systems}

In recent years, the proportion of 17-20 year olds progressing to $\mathrm{HE}$ has increased in England from just 19\% in 1990 to approximately 49\% in 2015-2016 (BIS, 2017) while the proportion of 18-20 year olds in Ireland has increased from $20 \%$ in 1980 to $52 \%$ in 2015 (Clancy \& Wall, 2000; HEA, 2015). Over this time a range of WP initiatives have been implemented in both national contexts. Yet, despite their prevalence, comparative research on WP policy and the specific measures adopted by HEls to recruit WP students both within and across country contexts remains under explored (for exceptions see Donnelly \& Evans, 2018). As a result, research studies that examine the characteristics of students entering higher education from similar cross-national WP programmes are limited, as are research studies that exam- ine the characteristics of students entering higher education from different WP programmes within selective universities. Thus, a comparative study of WP policy and initiatives at both the institutional level (within HEIs) and at the national level (country level) between Ireland and England is timely for a number of reasons. Firstly, both HE systems have experienced high rates of expansion coupled with a highly educated population in European terms. That is, in both contexts there is now more than a $20 \%$ difference in the number of students attending Higher Education since 2000, and in both contexts over $45 \%$ of the $25-34$ age group have acquired a higher education qualification. Secondly, trends in WP policy have become increasingly convergent in Ireland and England in terms of national target setting and accountability, making an interesting case study. In Ireland, the Higher Education Authority (HEA) continues the practice of setting national targets but has recently made HEls more accountable for WP offerings by demanding that each $\mathrm{HEI}$ states their institutional WP targets in a 'performance compact' ${ }^{1}$ since 2014 . This shift has been accompanied by a number of competitive funding streams provided by the Department for Education and Skills (DES) for HEls to implement evidence-based WP initiatives. In England, national target setting around WP is more recent (since 2015) and so, historically, HEls have had more discretion in setting their own parameters for WP. Access agreements have been in place for some time in England, since 2006 when income contingent loans were introduced. Since that time, the Office for Fair Access (OFFA) has had the remit to ensure that higher fees do not inhibit equity of access. Thus, HEls must agree an Access Agreement with OFFA in order to be able to charge higher fees, while retaining considerable agency in shaping institutional WP activities. Since April 2018, the Office for Students (OfS) has become the regulatory body for the English higher education sector. From the academic year 2019-2020, Access and Participation Plans and will have to be approved by the OfS, replacing Access Agreements.

The issue of institutional prestige adds a further layer of complexity when considering the implementation of WP policy. Young people from low socioeconomic groups are under-represented in the most selective universities in a number of country contexts (Jerrim, Chmielewski, \& Parker, 2015) including Ireland and England. In England, these students are particularly poorly represented in 'Old' (pre-1992) universities, as opposed to 'New' (post-1992) universities and especially so in Russell Group universities (Boliver, 2013, 2015; O'Sullivan, Robson, \& Winters, 2018; Robertson \& Hillman, 1997). In the Irish context, students from less advantaged backgrounds are more likely to be attending Institutes of Technology versus universities (Byrne \& McCoy, 2017; McCoy \& Smyth, 2011), while a significant majority of first year entrants in the most academically selective universities are drawn from private

\footnotetext{
${ }^{1}$ In 2014, each HEl entered into a 'performance compact' with the HEA undertaking how it would contribute to national objectives. The compacts provide for a roadmap for how performance is to be measured and a proportion of funding is contingent on performance.
} 
or fee-paying schools (Share \& Carroll, 2013). Despite the existence of a culture of selective admissions in the $\mathrm{HE}$ entry systems in both Ireland and England, it is important to keep in mind that progressive shifts have coexisted within selective universities, including the WP movement. That is, the last ten years have seen alternative entry routes to $\mathrm{HE}$ becoming more noticeable in national policy, with the use of contextualised admissions and the provision of foundation years becoming more common in both Ireland and England. However, where these routes fit within the stratified university system is under-explored, and the extent to which the characteristics of students who utilise these routes differ is relatively unknown. In addition, cross-national comparative studies have neglected how WP initiatives are perceived in the broader admissions processes in selective universities.

Access to selective universities is an important WP policy consideration given that graduate outcomes tend to be more favourable as the most sought employers favour and reward such graduates. For example, in England and the UK, graduates of more prestigious HEls are more likely to secure professional and managerial jobs and earn higher salaries than students attending $\mathrm{HEls}$ that are deemed to be less prestigious (Hussain, McNally, \& Telhaj, 2009). In the Irish context, research has identified that there is a wage premium to university attendance as opposed to attendance at an Institute of Technology, all else being equal (Kelly, O'Connell, \& Smyth, 2010). Furthermore, the competitive context of $\mathrm{HE}$ in each country means that the most selective universities have more resources, are commonly perceived to deliver the best education, and are positioned in top international rankings. Each of these aspects confer certain educational and career benefits that are not available in other institutions.

For quite some time, the admission system has been a concern in international studies on social stratification in higher education, given that the system and its rules represent the key mechanism through which access to $\mathrm{HE}$ is determined (Alon, 2011, in Israel; Boliver, 2013, in the UK; Byrne, Doris, Sweetman, Casey, \& Raffe, 2013, in Ireland; Karabel, 2005, in the US; Thomsen, 2018, in Denmark; Zimdars, Sullivan, \& Heath, 2009, in England). Both social closure theory (Weber, 1978) and social reproduction theory (Bourdieu \& Passeron, 1977) posit that selective universities adopt admission policies that match the cultural capital of their desired intakes, thus reproducing and maintaining advantage in securing admission for the privileged professional classes. What is of particular interest to us is the interpretation of the aims of WP initiatives and admission 'rules' by those who have responsibility for admission. Research studies involving those who are responsible for admission decision-making are still in their infancy in the social stratification literature (for exceptions see Bowman \& Bastedo, 2018; Stevens, 2007; Zimdars, 2010). As a result, relatively few research studies have explored the processes that HEls use to develop selection criteria and review applicant materials, the procedures for assessing applications, and the practices of those with responsibility for admissions. To this end, much less is known about the processes involved in admitting WP students, or how WP policy (or rule) enactment occurs within specific institutions. Admission policies for selective universities may be 'written' by Government or indeed by those within a university with responsibility for the strategic direction (such as a Governing Authority, which may or may not include those with responsibility for admissions). Thus, we also need to pay greater attention to the 'negotiation, contestation or struggle between different groups who may lie outside of the formal machinery of official policymaking' (Ozga, 2000, p. 13). As a result, our attention to those who are responsible for admission decisions is heightened, given that existing research has found that there is a certain amount of lee-way involved-that in the selective university context 'admission decisions are not formulaic' (Zimdars, 2010, p. 319). Therefore, interviews conducted with those involved in WP admissions form an important part of understanding the patterns of who is admitted to a selective university as a WP student, and the type of admission route taken, from a crossnational perspective.

\section{WP Policy Developments in Ireland and England}

Since the late 1990s, there have been several changes to WP policy in both Ireland and England to try to improve access to HE for under-represented socio-economic groups. As a result, HEls are beginning to move away from simplistic explanations of inequality to greater consideration of the complex nature of its causes, recognising that WP activities need to bridge gaps in human, social and cultural capital if students are to succeed in higher education. In this section, we focus on two key policy developments-namely, the use of contextualised admission and the provision of foundation years. While contextualised admissions and the provision of foundation years are distinct WP initiatives, they share some common characteristics. That is, both consider the context of the applicant and their circumstances along a range of dimensions; and both can potentially allow for reduced academic entry requirement, taking into consideration the long-term impact that socio-economic disadvantage can have on the educational attainment of young people.

\subsection{Contextualised Admissions}

Universities in Ireland and England are using a contextualised admission system as a means of increasing participation rates of disadvantaged students. In England, the idea of contextualising academic attainment on entry to HE can be traced back to at least the 1960s and 1970s and became more formalised as a process following the Schwartz Report (2014) which recommended that contextual admissions become part of fair admissions 
(Mountford-Zimdars, Moore, \& Graham, 2016; Schwartz, 2004). In the English context, students apply through a centralised admission system and can opt in by declaring contextual information as part of their undergraduate admissions application. ${ }^{2}$ Universities and colleges use contextualised admission differently, but typically those with responsibility for admissions in individual universities/colleges apply the contextualised indicators to assist with making conditional offers or offers to interview. $^{3}$ A second method uses applicant data to calculate individualised offers resulting in a reduced grade offer (a reduced academic requirement). Adopting a contextualised admission system means including a number of 'flags' on each application by those with responsibility for admissions during the admissions process, where each 'flag' represents a different indicator of disadvantage. In the English context, four types of flags or indicators are generally used: (1) individual-level; (2) arealevel; (3) school-level; and (4) participation in WP programmes or outreach activities. A survey of 68 universities in the UK in 2015 revealed that $84 \%$ were using some form of contextualised admissions, up from 37\% in 2012 (Sundorph, Vasilev, \& Coiffait, 2017).

In Ireland the Higher Education Access Route (HEAR) is a national, centralised contextualised admissions system. All universities and some Institutes of Technology use HEAR. As in the English context, applicants must 'opt in' to this admission system. That is, applicants must specifically apply to become 'HEAR Eligible', a process that has recently become part of the centralised HE application process undertaken by the Central Applications Office (CAO). Previously, at the time of data collection for this article, students had to submit applications to a specialised body tasked with contextualised admission, a function that was undertaken by those working in WP 'access' offices. In 2017, 7.5\% of all higher education applicants applied to become 'HEAR eligible', down from 10.6\% in recessionary Ireland in 2012 (Byrne et al., 2013; Nic Fhlannchadha, 2017). The Irish system also adopts four different types of pre-defined indicators of disadvantage which include a household income indicatorwhich applicants must meet to become HEAR eligibleas well as a combination of two other indicators at the (1) individual level, (2) school level or (3) area level (see Table 1). During the application process, candidates are either deemed 'HEAR eligible' if they meet three or more indicators, meaning that they can avail of a reduced grade offer for their course of preference if required. Given that higher education entry in Ireland is determined by performance in the Leaving Certificate (terminal examination at upper secondary), a quota system of reserved places for each course in each participating $\mathrm{HEI}$ then allows HEAR eligible students to compete against each other for places. As soon as the number of reserved places is filled, remaining HEAR students join the compe- tition for places with all other applicants. Research has found that those who are deemed to be 'HEAR eligible' are more likely to receive an offer of a place at higher education than all other higher education applicants (Byrne et al., 2013).

The use of the reduced grade mechanism is a key aspect of the contextualised admission process in both contexts. As indicated above, in some universities in England the contextual applicants may be either prioritised for a reduced grade offer at one or more grades below the standard offer, or alternatively guaranteed an interview. Research in the English context has consistently found that contextual information is used by institutions in a broad sense-where those in admissions take the information into consideration when making offers-rather than for reduced grade entry (Boliver, Crawford, Powell, \& Craige, 2017; Sundorph et al., 2017). Research in Ireland also reports considerable variation across universities/colleges and over time in the use of the reduced grade mechanism. Byrne et al. (2013) found that among the HEAR eligible applicants entering higher education between 2010 and 2012, the share who had received a reduced grade offer was in decline-down from $44 \%$ in 2010 to $33 \%$ in 2012 . Yet, HEAR eligible students fare as well as direct entry students in terms of progression beyond first year at $\mathrm{HE}$, irrespective of a reduction in academic requirements (Byrne et al., 2013). Likewise, in the English context, there is no evidence to suggest that entry through reduced academic requirements results in higher drop-out rates, lower completion rates or lower overall attainment at HE (Boliver et al., 2017).

There are some key differences between how Ireland and England use contextualised data. In the Irish context, the use of indicators is standardised across universities/colleges. That is, each of the institutions that use the contextualised admission approach apply the same indicators, and these indicators are now applied centrally rather than by individual institutions. In England onus is placed on individual institutions to decide their own contextualised admission system and they may choose among indicators, as there is no centralised, pre-defined category that universities are required to use. Recent research suggests that previous participation in widening access programmes is the most common contextual indicator used, with two-thirds of universities in England reporting that they take this into account than other indicators (Boliver et al., 2017). In the Irish context, Byrne et al. (2013) found that the majority of those who reached the status 'HEAR eligible' did so on the combination of income and medical indicators, coupled with either socioeconomic status, school or area indicators.

Whether contextualised admission entry is overseen at a national level as in the case of Ireland, or operated by individual institutions as in the case of England, it does not come without problems. That is, a lack of

\footnotetext{
2 The Universities and Colleges Admissions Service (UCAS) has this function in the English context.

${ }^{3}$ As indicated above, in some universities/colleges in England the contextual applicants may be prioritised for a reduced grade offer at one or more grades below the standard offer-for example, $A A B$ or $A B B$ at A-level rather than AAA.
} 
transparency is an issue for both systems. In Ireland there is a lack of transparency around precisely how much of a grade reduction is given to HEAR applicant students across universities (Byrne et al., 2013), while in the English context Boliver et al. (2017) have also found that there is a lack of transparency in the use of contextualised admissions across HEls.

\subsection{Foundation Years}

Universities in Ireland and England have also developed foundation year programmes ${ }^{4}$ as a way of supporting students to transition into university and to supplement the 'attainment gap'. Across both contexts, these programmes are broadly intended for those who do not meet the formal entry qualifications for their chosen degree and are designed to prepare students for degree level study (O'Sullivan et al., 2018). ${ }^{5}$ That is, in both countries, students would typically not be permitted entry to the first year of their preferred undergraduate programme without the foundation year programme.

There is now greater momentum around university provision of foundation year programmes in the UK more broadly, and currently there are over 700 programmes available through University Central Admission System (UCAS, 2017), with considerable variation in terms of what they offer, and their target student. In the English context, these programmes have taken three directions; provision for international students, provision for the general student population, and provision to widen the participation rates of under-represented groups in university, to include mature students or students from low socio-economic backgrounds. Foundation years have evolved from pre-university entry courses provided in the further education (FE) sector or provided as collaborative FE/HE projects (Sanders \& Daly, 2013).

In Ireland, foundation years have traditionally been delivered in the university context and have targeted under-represented student groups. Recent WP policy has advocated the continued delivery of foundation years largely orientated towards young adults and mature students but with a remit to promote links between $\mathrm{HE}$ and FE providers (HEA, 2015). Unlike in England, application to foundation year programmes are made directly to the university/HEI. Currently in Ireland, each of the seven universities run foundation year programmes for underrepresented groups.

Foundation year programmes within and across country contexts also vary in the type of supports they offer students. However, for those from underrepresented socio-economic groups and mature students, the supports specifically seek to facilitate the development of social and cultural capital alongside generic academic skills and/or subject specific content. In doing so, the programmes recognise that the challenges facing underrepresented groups in $\mathrm{HE}$ are complex. Thus, they seek to support the development of peer relationships, support academic ability and growth in students' confidence; prevent students feeling under-qualified compared to their peers, and aim to provide access to forms of bridging capital that support retention and progression (Heil, Reisel, \& Attewell, 2014; O'Sullivan et al., 2018). A review of foundation years in Ireland demonstrated the effectiveness of the model in supporting under-represented students to access higher education (Murphy, 2009), and evidence from one selective Irish university found that retention and graduation rates were in line with those of direct entry students (Share \& Carroll, 2013). In England, evidence is rather sparse although some research shows that foundation year students fare as well as direct entry students in the first year of study (Sanders \& Daly, 2013). O'Sullivan et al. (2018) also report how a foundation year programme delivered in a selective university is supporting students to integrate into the prestigious environment. Boliver et al. (2017) also recommend that foundation year provision should be increased in England, with greater targeting of those from disadvantaged backgrounds.

There are commonalities and differences between foundation year programmes in the two selective universities under investigation in this article (see Table 1). In terms of commonalities, applications are made directly to the University ${ }^{6}$, and students are assessed on application, interview and writing competency. However, differences also exist. Firstly, in the English selective university, the indicators that are used to determine entry to the foundation year were adapted from the existing contextualised admission indicators for entry to the university. In the Irish context, it is the other way around-as the national contextualised admission indicators were adapted from pre-existing foundation year provision. Secondly, while each selective university employs indicators of disadvantage for admission, some differences exist in the classification of socio-economic disadvantage. As shown in Table 1, in Ireland income level is a key indicator for socio-economic disadvantage, alongside parental socioeconomic background, school type, residential postcode, eligibility for a medical card and welfare status. In the UK, the extension of indicators allowed for a more nuanced approach to WP than currently was used in the institution. The approach taken required that applicants meet the indicators of income and/or low parental socioeconomic group at the individual level, alongside area level indicators capturing the proportion of young people participating in $\mathrm{HE}(\mathrm{POLAR})^{7}$, the socio-economic profile of the area (ACORN) ${ }^{8}$, and school characteristics (school

\footnotetext{
${ }^{4}$ In Ireland, these are known as access courses or foundation courses. For the purposes of consistency this article will use the term 'foundation year' that incorporates those offered in both the UK and Ireland.

${ }^{5}$ For further information on the development of foundation year programmes in the UK see Sanders, Daly and Fitzgerald (2016).

${ }^{6}$ In this respect, the English foundation year under investigation deviates from the typical national application procedure.

${ }^{7}$ POLAR: Participation of Local Areas classification.

${ }^{8}$ ACORN: A tool used to characterise a postcode according to socio-economic status.
} 
Table 1. Key characteristics contextualised admission in Ireland and foundation years in two selective universities in Ireland and England.

\begin{tabular}{|c|c|c|c|}
\hline & $\begin{array}{l}\text { Foundation Year, Selective } \\
\text { University in England }\end{array}$ & $\begin{array}{l}\text { Foundation Year, Selective } \\
\text { University in Ireland }\end{array}$ & $\begin{array}{l}\text { Ireland Contextualised } \\
\text { Admissions }\end{array}$ \\
\hline $\begin{array}{l}\text { Application } \\
\text { Method and } \\
\text { Material Required }\end{array}$ & $\begin{array}{l}\text { Direct Application to the University } \\
\text { Application }+ \text { Written Work }+ \\
\text { Interview(s) }\end{array}$ & $\begin{array}{l}\text { Direct Application to the University } \\
\text { Application }+ \text { Written Work }+ \\
\text { Interview(s) }\end{array}$ & $\begin{array}{l}\text { Application via } \\
\text { Central Applications } \\
\text { Office (CAO) }\end{array}$ \\
\hline $\begin{array}{l}\text { Eligibility \& } \\
\text { Indicators/Flags }\end{array}$ & $\begin{array}{l}\text { Applicants must have studied at a } \\
\text { state school for entire school } \\
\text { career, AND/OR have been in the } \\
\text { care of a local authority AND/OR } \\
\text { meet the Individual and socio- } \\
\text { economic indicators }\end{array}$ & $\begin{array}{l}\text { Applicants must have attended } \\
\text { a school linked to the access } \\
\text { service in the HEI, as well as } \\
\text { meet the household income } \\
\text { threshold, and meet two other } \\
\text { indicators of disadvantage. }\end{array}$ & $\begin{array}{l}\text { Applicants must meet } \\
\text { the household income } \\
\text { threshold, and meet } \\
\text { two other indicators } \\
\text { of disadvantage }\end{array}$ \\
\hline $\begin{array}{l}\text { Household } \\
\text { Income }\end{array}$ & $\begin{array}{l}\text { Household income below } £ 42,875 \\
(€ 48,905)\end{array}$ & Household income below $€ 45,790$ & \\
\hline SES & \multicolumn{3}{|c|}{ All parents present must belong to an under-represented socio-economic group in $\mathrm{HE}$} \\
\hline Medical Card & & \multicolumn{2}{|c|}{ In receipt of a medical card for at least 12 months } \\
\hline $\begin{array}{l}\text { Social Welfare } \\
\text { Recipient }\end{array}$ & & \multicolumn{2}{|c|}{ In receipt of a means-tested social assistance payment } \\
\hline School & $\begin{array}{l}\text { The school that you attended for } \\
\text { your GCSEs }{ }^{9} \text { scored below the } \\
\text { national average for GCSE Results } \\
\text { OR the school that you are } \\
\text { attending for your A Levels }{ }^{10} \\
\text { scored below the national } \\
\text { average for the 'Average Point } \\
\text { Per Academic Entry' }\end{array}$ & $\begin{array}{l}\text { Applicants must have attended } \\
\text { a school linked to the access } \\
\text { service in the HEI, have } \\
\text { completed } 5 \text { years in a DEIS }{ }^{11} \\
\text { school-a school with a } \\
\text { concentration of disadvantaged } \\
\text { students }\end{array}$ & $\begin{array}{l}\text { Have completed } 5 \text { years } \\
\text { in a DEIS school-a } \\
\text { school with a } \\
\text { concentration of } \\
\text { disadvantaged students }\end{array}$ \\
\hline Area & $\begin{array}{l}\text { POLAR: live in an area with a } \\
\text { smaller proportion of young } \\
\text { people participating in higher } \\
\text { education. } \\
\text { ACORN code: live in an area of } \\
\text { socio-economic disadvantage }\end{array}$ & \multicolumn{2}{|c|}{$\begin{array}{l}\text { Live in an area that is disadvantaged, very disadvantaged or } \\
\text { extremely disadvantaged }\end{array}$} \\
\hline $\begin{array}{l}\text { Academic } \\
\text { Entry } \\
\text { Requirements }\end{array}$ & $\begin{array}{l}\text { Yes, one grade typically below } \\
\text { the traditional offer from the } \\
\text { university of AAA. Applicants } \\
\text { must have A Levels, Scottish } \\
\text { Highers or International } \\
\text { Baccalaureate. BTEC National } \\
\text { may be eligible }\end{array}$ & $\begin{array}{l}\text { Yes }-5 \times 06 / 1 \times \mathrm{H} 5 \text {. Applicants } \\
\text { must have passed English } \\
\text { and Math } \\
\text { Distinction in the LCA, } \\
\text { or QQI-FET Level } 5\end{array}$ & $\begin{array}{l}\text { Reduced LC points } \\
\text { basis. Sliding points } \\
\text { scale in play typically } \\
10 \% \text { reduction of } \\
\text { points-deductions } \\
\text { greater for higher } \\
\text { point courses }\end{array}$ \\
\hline Residency & $\begin{array}{l}\text { Applicants must be eligible for } \\
\text { 'home fee' status }\end{array}$ & \multicolumn{2}{|c|}{$\begin{array}{l}\text { Applicants must be eligible for the Government Free Fees } \\
\text { Scheme or EU Fees }\end{array}$} \\
\hline Age & $\begin{array}{l}\text { Applicants must be aged } 19 \\
\text { or under }\end{array}$ & $\begin{array}{l}\text { Applicants must be } 21 \text { years of } \\
\text { age or under }\end{array}$ & \\
\hline Duration & 1 year, full-time & 1 year, full-time & $\begin{array}{l}\text { 3-4 year depending on } \\
\text { the Degree }\end{array}$ \\
\hline Level of study & Level 3, same as A levels & Level 6 Special Purpose & Levels 6-8 \\
\hline
\end{tabular}

\footnotetext{
${ }^{9}$ GCSEs: Examinations undertaken by $14-16$ years old in England.

10 A-Levels: Upper secondary qualification in England.

${ }^{11}$ DEIS-Delivering Equality of Opportunity in Schools-is an initiative of the Department of Education and Skills in Ireland which seeks to improve the opportunities for those attending schools with high concentrations of children from disadvantaged backgrounds.
} 
Table 1. (Cont.) Key characteristics contextualised admission in Ireland and foundation years in two selective universities in Ireland and England.

\begin{tabular}{|c|c|c|c|}
\hline & $\begin{array}{l}\text { Foundation Year, Selective } \\
\text { University in England }\end{array}$ & $\begin{array}{l}\text { Foundation Year, Selective } \\
\text { University in Ireland }\end{array}$ & $\begin{array}{l}\text { Ireland Contextualised } \\
\text { Admissions }\end{array}$ \\
\hline $\begin{array}{l}\text { Institutional } \\
\text { Responsibility } \\
\text { for Foundation } \\
\text { Year Students }\end{array}$ & $\begin{array}{l}\text { College responsibility for Foundation } \\
\text { Year students (not Departments) }\end{array}$ & Responsibility of the University & \\
\hline $\begin{array}{l}\text { Direct entry to } \\
\text { Degree course }\end{array}$ & $\begin{array}{l}\text { Progression not guaranteed. } \\
\text { Application made through UCAS } \\
\text { in November }\end{array}$ & $\begin{array}{l}\text { Progression is guaranteed. } \\
\text { Application made through CAO } \\
\text { February }\end{array}$ & Students already in degree. \\
\hline $\begin{array}{l}\text { Tuition and } \\
\text { Accommodation }\end{array}$ & Free Tuition + Stipend & Free Tuition + Bursary & $\begin{array}{l}\text { Some HEls offer a stipend; } \\
\text { students may be eligible for } \\
\text { a grant. }\end{array}$ \\
\hline
\end{tabular}

type, school pre and post 16 ranking). Finally, in terms of inter-institutional linkages, the foundation year in the Irish context is 'tightly coupled' as it requires that applicants attend schools linked to the selective university. This is a national characteristic, shaped by Irish WP policy approach whereby universities are allocated schools that have low progression rates to higher education, to facilitate the targeting of WP activities. In contrast, the foundation year under investigation in the English context is 'loosely coupled'.

\section{Methodology}

The empirical data used in this article derives from a number of research projects conducted at a selective university in England and at a selective university in Ireland. The first was a cross-national study of WP students in Ireland and England ${ }^{12}$. The second was a national evaluation of the HEAR scheme in Ireland (Byrne et al., 2013). The quantitative data presented in Table 2 is drawn from baseline data from the O'Sullivan et al. (2018) study, and three groups are represented: (1) foundation year students attending a selective university in England; (2) foundation year students attending a selective university in Ireland; and (3) those who gained entry through the contextualised admission route in Ireland (i.e., those who were deemed to be HEAR eligible) in 2016 and 2017. The qualitative data consisted of 8 semi-structured interviews conducted with academic staff with responsibility for admission to the selective university in England, a focus group of admission officers, as well as 2 interviews with WP access staff working at the selective university in Ireland. In England, the fieldwork consisted of interviews with academic staff with responsibility for admission across a range of colleges. In Ireland, interviews were conducted with WP staff, co-ordinators of the national contextualised admission programme and admission staff. For the pur- poses of anonymity, all respondent quotes are referred to in the article as 'England' or 'Ireland'. The time period of the fieldwork was between September and May of 2016-2017 for the former and February to May 2013 for the latter. The study used Interpretative Phenomenological Analysis (IPA) - a qualitative approach that explores in detail how participants are making sense of their personal and social world (Smith, Flowers, \& Larkin, 2009). In this context, rather than attempting to produce an objective statement of the admissions process and an account of the actual work conducted by those involved in admissions, IPA techniques were adopted to explore the participants' individual experiences and personal reflections on the admissions process and rules. To this end, the personal experiences and perceptions of the how the foundation year and the contextualised admissions process fit within the selective university WP agenda was also of concern in the methodological approach. The key aim of the analysis was to make meaning of the beliefs and constructs that emerged from the interviews. Close reading of the interview transcripts was followed by documentation of emerging themes and their connections.

\section{Findings}

This section presents the results of a descriptive analysis of the characteristics of participants who have gained admission through the foundation year route in each selective university in Ireland and England, and those who have gained admission through the contextualised admission process in the selective university in Ireland. ${ }^{13}$ While limited in its analytic capability and cross-sectional nature, the data presented provides a descriptive snapshot of the characteristics of students who have secured admission through different WP admission routes. In particular, it allows to explore: (1) a comparison of how the student intake into foundation year programmes differ across two selective universities in Ireland and in

\footnotetext{
12 Irish Research Council Grant awarded to Katriona O'Sullivan.

${ }^{13}$ Similar data for those entering through contextualised admission in the selective university in England was not available to the research team.
} 
England; and (2) how the student intake to a selective university in Ireland differs according to the foundation year and contextualised admission routes. Key characteristics captured by the data include gender, family structure, race/ethnicity, parental education, parental occupation and previous educational attainment (equivalised).

\subsection{How Foundation Year Students Differ in Two Selective Universities in Ireland and England}

As indicated above, the data allow a cross-national comparison of how the student intake into foundation year programmes differs across two selective universities in Ireland and in England. The findings are presented in Table 2. Clearly, the size of the cohort is greater in the foundation year offered in the selective university in Ireland than its counterpart in England. However, there are also some striking similarities-each capture a higher share of females relative to males. While females are more likely to attend HE in the Irish context than males, this finding is particularly interesting in the English context given that Zimdars (2010) found that females were less likely to receive an offer for the selective university in England through the contextualised admission process, all else being equal. Lone parenthood is relatively high in both intakes in Ireland and England. In the UK, the percentage of dependent children living in lone parent families is $21 \%$ (Office of National Statistics, 2017) and in Ireland $18 \%$ of all family units are one parent families (CSO, 2016). In terms of family structure, each of the foundation years attract a high share of students from lone parent families, and those living with grandparents or other family members (51\% of the Irish and $61 \%$ of the English intake). Ethnic minority groups have greater participation in the foundation year in England compared to Ireland ( $61 \%$ relative to $25 \%$ respectively). While there is more ethnic diversity in the English population than the Irish population, there is also considerable less attention paid to issues of ethnicity and race in WP and HE policy more generally, in Ireland than in England. ${ }^{14}$

The equivalised previous academic attainment of the foundation year students in the selective university in England was substantially greater than that in the selective university in Ireland. This observation displays the nuances that exist between selective universities in Ireland and England in selecting WP students. Such disparity may reflect the strong drive to maintain high academic standards of the English selective university-a theme that emerged in our analysis of the qualitative data (see in the section below). A practice of maintaining high entry requirements for WP students can be conceptualised as a form of 'cream skimming', where WP initiatives take the 'most intelligent' students from the low SES community, and place them in the 'top' universities, ignoring the societal and structural barriers which limit education progression, placing the responsibility for change on the low SES student in a manner that is similar to 'victim blaming' (Jones \& Thomas, 2005, p. 617). With regard to parental education levels, both foundation year programmes attract students from the full range of academic backgrounds. However, clearly the foundation year programme in Ireland is capturing a greater proportion of students whose parents have very low levels of education ( $42 \%$ compared to $34 \%$ of students), while the opposite is also true- $22 \%$ of foundation year students in the English selective university had parents with a HE qualification compared to just $9 \%$ in Ireland. In terms of parental employment, both foundation year programmes capture a similar share of young people from unemployed households, and those whose parents work in less secure employment (hourly paid jobs).

\subsection{How Foundation Year and Contextualised Admissions Students Differ in a Selective University Ireland}

The data also allow an examination of how different WP routes (foundation year versus contextualised admission) differ in terms of the student intakes that they admit at the selective university in Ireland. As shown in Table 2, the number of students accessing the university through each of the WP entry routes varies quite considerably, with the contextualised admission route capturing a larger number of entrants relative to the foundation year route. This is interesting given that our descriptive analysis shows that the characteristics of students who are admitted through each of the routes differ substantially. That is, students who experience greater levels of disadvantage in terms of family structure, parental education and household employment have greater levels of participation in the foundation year than those who were admitted through contextualised admission. For example, $51 \%$ of students admitted through the foundation year are from single parent households compared to $42 \%$ admitted through contextualised admission. With regard to parental education levels, both WP initiatives attract students from the full range of parental education levels. However, clearly the foundation year is a capturing a greater proportion of students whose parents have very low levels of education ( $24 \%$ of foundation year students relative to $16 \%$ of contextualised admission). Furthermore, in terms of parental employment, the foundation year captures a greater share of students coming from unemployed households ( $12 \%$ compared to $3 \%$ ). Finally, student average grades are significantly lower for the foundation year intake than the contextualised admission intake (by 114 points), meaning that foundation year students would not gain entry to the selective institution based on the grade average, even when the selective university is using contextualised admission.

\footnotetext{
$1418 \%$ of the population in Ireland declared an ethnicity other than 'White Irish' in the 2016 Census of Population. In the English context, statistics based on the Census of Population 2011 indicate that 40\% of residents in England and Wales identified with either an Asian, Black, Mixed or Other ethnic group.
} 
Table 2. Characteristics of Students Entering the WP Admission Routes in two selective universities in Ireland and the UK.

\begin{tabular}{|c|c|c|c|}
\hline \multirow[b]{2}{*}{$\%$} & \multicolumn{2}{|c|}{ Foundation Year } & \multirow{2}{*}{$\begin{array}{c}\text { Contextualised Admissions } \\
\begin{array}{c}\text { Selective University } \\
\text { Ireland }\end{array}\end{array}$} \\
\hline & $\begin{array}{l}\text { Selective University } \\
\text { England }\end{array}$ & $\begin{array}{l}\text { Selective University } \\
\text { Ireland }\end{array}$ & \\
\hline Number & 18 & 54 & 187 \\
\hline \multicolumn{4}{|l|}{ Gender } \\
\hline Female & 72.2 & 66.7 & 64.6 \\
\hline Male & 27.8 & 33.3 & 31.8 \\
\hline \multicolumn{4}{|l|}{ Family Structure } \\
\hline Single Parent Family & 50.0 & 41.5 & 42.0 \\
\hline Two Parent Family & 38.9 & 49.1 & 58.0 \\
\hline \multicolumn{4}{|l|}{ Living with Grand Parent/Relative/ } \\
\hline Foster Care & 11.1 & 9.4 & 0.0 \\
\hline \multicolumn{4}{|l|}{ Race/Ethnicity } \\
\hline White & 38.9 & 75.0 & 77.4 \\
\hline Minority Ethnic/Racial Groups & 61.1 & 25.0 & 22.6 \\
\hline \multicolumn{4}{|l|}{ Previous Attainment } \\
\hline Average Attainment & 436 & 344 & 458 \\
\hline \multicolumn{4}{|l|}{ Parental Education } \\
\hline Primary Level Only & 16.7 & 24.5 & 8.6 \\
\hline Junior Cert/GCSE & 16.7 & 0.0 & 7.5 \\
\hline Leaving Cert/A Levels & 5.6 & 18.9 & 25.1 \\
\hline Some college/FE & 11.1 & 17.0 & 21.9 \\
\hline Degree/Higher Degree & 22.2 & 5.7 & 13.9 \\
\hline Masters or Phd & 0.0 & 3.8 & 5.8 \\
\hline Don't Know & 11.1 & 11.3 & 8.6 \\
\hline \multicolumn{4}{|l|}{ Parental Employment } \\
\hline Unemployed & 15.4 & 11.8 & 2.8 \\
\hline Employed & 84.6 & 88.2 & 97.2 \\
\hline \% Employed on an Hourly Pay Basis & 30.8 & 35.3 & 49.5 \\
\hline
\end{tabular}

\subsection{How Those Involved in Selective University Admission Perceive the WP Admission Routes}

In an attempt to better understand how HEls enact WP policy, the qualitative findings sought to unpack how those with responsibility for admissions in each context perceived the different WP admission routes. In the following section, three themes which emerged from the analysis of the qualitative data are discussed: (1) how those with responsibility for admissions understand the dynamics of processes of inequality in educational attainment; (2) how those with responsibility for admissions make distinctions between each of the WP admission routes; and ( 3 ) how discussions about the WP initiatives are located within the broader context of the selective institution.

\subsubsection{Understandings of Processes of Inequality in Educational Attainment}

For the most part, those involved in admission decisionmaking in the English selective university demonstrated an understanding of the role played by long-term experiences of socio-economic disadvantage in the home on producing differences in educational achievement. Typical comments included:

They're [foundation year] students coming from really, really poor backgrounds...very disadvantaged households with very low incomes...the reasoning is that if they didn't get the predicted grades, it's just because of circumstances, and actually you can't fix it in the A level stage, it is an ongoing process and it needs a longer time to, you know, get these students up, up to a standard that they're capable of. (England)

Now...a student at that school [in a disadvantaged area], having gone through education in that area cannot achieve an Oxford or Cambridge offer. There might be one person in a decade in the school that has achieved $A^{*}, A, A$, if the person who got an $A^{*}$ also happened to get $A s$ in the other two subjects. That's very different from a school which occasion- 
ally produces $A^{*}$ s, occasionally produces Oxford and Cambridge people, have obviously the teaching infrastructure to do it. (England)

However, while schools were often central to this discussion, their reference appeared to be vague, with little specific elaboration as to how schools structure disadvantage. That is, research has shown that schools structure disadvantage through inequalities in access to informed career guidance, the persistence of tracking and ability grouping for key subjects, and inequalities in access to resources to supplement learning and assessment at school. Yet, the interviews did not yield such indepth understanding of how schools structure processes of inequality in educational attainment. Rather, there was a strong discourse around the failures of the school system in preparing young people for entry to selective universities. In such instances in the English selective university, the rationale provided for the need for a foundation year programme was 'to make up for things that were missed in their schooling' or for universities more generally to 'take on...the failing of the school system'. This was in contrast to the Irish context, where those involved in admission decision-making and verifying indicators of disadvantage are WP access staff, there was less failure attributed to schools, and a stronger recognition of the supportive role that schools can play:

When you are working with schools for outreach purposes, [school] staff have a huge understanding and knowledge of the students and their backgrounds and understanding where they come from. (Ireland)

Those involved in admissions in both contexts also acknowledged the role of local area disadvantage on individual attainment. While awareness was evident of the under-representation of young people from the most deprived areas in England, it was often articulated that the POLAR and ACORN indicators produced 'a mixed response'. At times, those involved in admissions found the area indicators to be less relevant to the individual applicant than school flags due to potential measurement error. In contrast, a more reflective understanding of the impact of multiple disadvantage over life course was evident in the Irish context, with staff responsible for admissions recognising the need for multiple indicators to tackle processes of inequality. Issues around the ability to verify some of the indicators in the Irish context also arose, but largely with regard to socio-economic position as opposed to the area-based measures:

We wanted to move away from just looking at income, to looking at where people grew up. The kinds of schools they had gone to, their socioeconomic backgrounds, in order to capture the kind of cultural educational disadvantaged instead of just looking at a cut off, income cut off point. You know, we felt that we wouldn't get, we wouldn't capture the kinds of stu- dents we wanted to have if we just focused solely on income. (Ireland)

Yet, in discussions pertaining to (dis)advantage, key distinctions were continuously made between school types, with emphasis placed on the concentration of advantage/disadvantage in schools. That is, distinctions were made between those attending 'state' schools versus those attending private/independent schools in England, or the DEIS/non-DEIS distinction in Ireland-in other words, schools with/without high concentrations of students from disadvantaged backgrounds. In this process, schools were clearly positioned by HE staff, but so too were students, contributing to a deficit discourse. For example, candidates were often referred to as 'the best candidates' or 'the weakest/strong candidates'. The use of binaries in this regard tended to be less prevalent among the contextualised admission route administrators in the Irish context, who had more direct interactions with WP students seeking to access the selective university than all others interviewed.

\subsubsection{Distinctions Made between the WP Routes}

The strengths of using contextualised admissions in the selective university in Ireland were offered by staff, and in particular the advantage of nationalising/centralising the route.

The universities had gotten to a point where...the number of students being admitted to the scheme [HEAR] had plateaued. But a lot of institutions were not fitting their quotas so it needed you know, we wanted more applicants, we wanted more students but the way the scheme was set up it couldn't deliver. (Ireland)

In these discussions in the Irish context, the national contextualised admission approach was viewed to be important in 'embedding what had been local (institutional) schemes and embedding them into a national system', but also the commitment of an independent body-the Central Applications Office-to ensure that each $\mathrm{HEI}$ 'was approaching application and assessment so we were being completely fair and consistent across the board to every student that applied to the it'. However, in the interviews and focus groups, there was also considerable concern among those involved in HEAR admission decision-making as to whether it was attracting the types of students that it sought to attract. That is, concerns were raised regarding the limitations to the contextualised admission approach in attracting the most disadvantaged students. To this end, it was recognised that multiple entry paths were required to tackle underrepresentation of the most disadvantaged groups:

Students would have different requirements...so if you tick all six indicators versus you tick three, 
chances are the person who ticked six indicators for here [a selective $\mathrm{HEI}$ ] needs greater support than the person who's ticked three. So I'm personally not in favour of a one size fits all for every single student because depending on the $\mathrm{HEl}$ that they go to and their own individual circumstances they require different kinds of supports. (Ireland)

Reflecting the infancy of the foundation year at the selective university in England, there was less consensus regarding it. While many viewed that the foundation year represented a safety-net to support young people growing up in deprived areas in accessing selective universities, the concept of a reduced grade entry was at times viewed as too radical. At times, staff suggested building stronger institutional linkages with schools, adopting local area interventions, and employing more outreach activities as opposed to specifically providing a foundation year:

But I think there's actually quite a lot going on in the university to encourage students from different backgrounds to do that...so....we really target students in those areas to apply and then, if they apply, there's a separate route for [foundation year] students sort of rescuing them. (England)

I think, routine you know, work with year tens, work with students repeatedly...go into your areas and bring them up for a week, teach them all of these skills that you're teaching this very small number...try to get the tutors involved. You know, the tutors are involved now but they weren't involved before. (England)

\subsubsection{Balancing Institutional Standards and Fairness}

The complexity of selection was a frequent theme and 'fairness' was constructed in different ways throughout the interviews in both contexts. In the selective institution in England, the use of opening offers, whereby WP students received a conditional offer dependent on meeting the academic standard, was viewed to be the fairest process, despite recognition that the institution was not doing enough to widen the participation rates of low SES students:

We would rather make more offers than accept people who haven't made their conditions.... If they've not made the grades that we predicted and not made what they need for entry...typically we wouldn't take them and that's why we have a big open pool, because these people do make their conditions and we think that's the fairest way. (England)

Fairness was typically described in two ways: personal and institutional, and respondents appeared conflicted when asked to consider the reduced grade entry mecha- nism that is central to foundation year entry. Typical comments included:

I mean, you want to be fair as well, right, so you want to make sure that everybody puts the same standard and although we clearly know it's not the case, it's much easier to get you're $A^{*} s$ if you come from a tutoring background and come from a really nice private school you know. (England)

A harmony between institutional standards and personal understandings of educational disadvantage and fairness was evident in the interviews in both contexts. While stories of individual staff members who they had 'went that extra mile' to support the entry of students were common, running alongside these stories were concerns about maintaining institutional 'academic standards'. Even the most liberal of those with responsibility for admissions were focused on the limits of potential academic growth of individuals, and how the presence of a foundation year could influence how the institution is perceived. In such instances, the provision of a foundation year represented a greater institutional 'risk' to maintaining the wider institutional goals of the selective university, than the use of contextualised admission:

[There are] academic implications because we are admitting students who didn't make their grades. I think that they have got a reputation to keep high in that they're not dropping their standards and I think that's how they want to be perceived and how actually we all want to be perceived as...a high achieving place. (England)

For some, a discourse around meritocracy was evident, and this was about displacing others who had earned a place:

Every HEAR place is displacing somebody that may have more points but isn't HEAR eligible, so there is a kind of a conundrum there. (Ireland)

I think it's this kind of idea of fairness, right? Like, if someone's achieved higher metrics it would seem unfair to not give them a place and give a place to someone else. Although, mitigating circumstances and contextualising scores will be taken into account and people will get bumped by these kinds of thing. (England)

If you sort of went through and picked up all the access candidates who were right at the top of scores, who didn't get taken, then you would have a group of people who wouldn't need a foundation year. (England)

In Ireland, those with responsibility for admissions were largely access personnel, who also worked directly with students. In the interviews, this group typically demonstrated a broader understanding of educational disad- 
vantage, and advocated the need for alternative routes into HE. This group could more clearly understand the distinction between academic potential and academic achievement, understanding the role that cumulative disadvantage plays, arguing for the use of alternative admission routes beyond the use of contextualised admission in selective universities, seeing such admission routes as essential for students who do not meet the HEAR academic standard.

\section{Conclusion}

This article sought to establish the characteristics of students entering selective universities in Ireland and England through different WP admission routes, while exploring how those with responsibility for admissions in both contexts perceive WP initiatives. The results indicate that students entering the selective institutions through these routes are more likely to come from loneparent families, and those entering through foundation years have greater levels of disadvantage in terms of family history of education and family occupation, compared to their counterparts who gain entry through contextualised admission. These results highlight the value of considering heterogeneity within diverse groups, and how the use of a range of WP entry routes to selective institutions work to meet the needs of all students, rather than the high performing disadvantaged student group (Thomas, 2011). In showing how the student groups entering selective HEls through these routes differ, the research highlights lone parenthood as something that may also be considered in future as an indicator of educational disadvantage.

Analyses of qualitative interviews highlight the complexities faced by staff with responsibility for admissions in selective universities, but also how broad national WP goals can clash with institutional culture. That is, broad national WP goals which seek to promote the act of relaxing academic entry requirements in order to reduce the impact that long-term disadvantage can have on educational attainment can clash with an institutional drive towards excellence and academic standards. The ethos of the HEI has a strong influence on the admissions environment in selective universities, and makes institutional/cultural rules regarding admission appear normative, universal and taken-for-granted (McDonough, 1997 , p. 12). For example, in the selective university in England, those with responsibility for admission demonstrated caution when considering foundation years as a viable WP initiative. The findings illustrate the difficulties faced by institutions when considering the WP agenda; it shows how putting WP policy into practice is a process which is complex and can involve different interpretations of policy ideas, and considerations of how well the policy fits with the overall ethos of the university.

The evidence from the foundation year in the selective English university shows that relaxing the academic standard further (as well as contextualising student ap- plication data) results in a more diverse student intake. However, it is also the case that this proposed practice clashes with the dominant ethos of the institution, which emphasises academics over all else. This is in contrast to the foundation year in the selective university in Ireland in some respects-while those with responsibility for admissions demonstrate concerns about meritocracy, and a model whereby affluent and able students are potentially being displaced, there is a general acceptance that student capability is impeded in situations of educational disadvantage. Admissions staff who were working more closely with WP students were most liberal in their views, and more likely to advocate for several routes into the selective university. As indicated in the methodology section above, those with responsibility for admissions may fall inside or outside of the formal machinery of policy making within the $\mathrm{HEI}$. That is, they participate in the building up of WP policies, but also have agency to enact or resist WP policy.

Finally, the differences observed in academic attainment on entry between foundation year students in the selective universities in Ireland and England reflect a stronger drive towards academic standards, as seen more broadly in the UK admissions rhetoric. This is of interest when considering the contrasting macro WP policy landscape in both countries. In England, individual HEls have the task of developing WP initiatives that suit their own institutional (local) context. Thus, WP is a process, the terms of which are agreed by those with power over the strategic direction of the HEI (such as a Governing authority), and institutional WP policy is then is enacted/interpreted by key actors working within the selective university. Given that it was academics that often occupied such positions in the English context, factors such as whether the policy was mandatory or recommended, or how well the policy was perceived to fit with the ethos of the institution shaped decision making around admission. In the Irish context, the HEA sets national WP targets, accompanied with some institutional accountability. While there is still room for WP policy to be enacted/interpreted locally in this model, the number of contextualised admission places allocated for each $\mathrm{HEI}$ is somewhat independently managed by a centralised body; ensuring that all HEls are contextualising admissions for at least $10 \%$ of the student body. However, in both country contexts, the enactment of WP policy highlights the persistence of mechanisms of social reproduction and social closure at play in selective universities.

\section{Acknowledgements}

This work was supported by the Irish Research Council (206208.14450), the Irish Universities Association/HEAR DARE Strategic Development Group and was also partially supported by a Seedcorn Grant from the Department of Education, University of Oxford. Delma Byrne and Katriona O'Sullivan are joint first (major) authors of this article. 


\section{Conflict of Interests}

The authors declare no conflict of interests.

\section{References}

Alon, S. (2011). The diversity dividends of a need-blind and color-blind affirmative action policy. Social Science Research, 40(6), 1494-1505.

BIS. (2017). Participation rates in higher education: Academic years 2006/07-2015/16. Statistical first release. London: Department for Business, Innovation and Skills.

Boliver, V. (2013). How fair is access to more prestigious UK universities? The British Journal of Sociology, 64(2), 344-364.

Boliver, V. (2015). Lies, damned lies, and statistics on widening access to Russell Group universities. Radical Statistics, 113, 29-38.

Boliver, V., Crawford, C., Powell, M., \& Craige, W. (2017). Admissions in context: The use of contextual information by leading universities. London: Sutton Trust.

Bourdieu, P., \& Passeron, J. C. (1977). Reproduction in education, society and culture. London: SAGE.

Bowman, N. A., \& Bastedo, M. N. (2018). What role may admissions office diversity and practices play in equitable decisions? Research in Higher Education, 59(4), 430-447.

Byrne, D., \& McCoy, S. (2017). Effectively maintained inequality in educational transitions in the Republic of Ireland. American Behavioral Scientist, 61(1), 49-73.

Byrne, D., Doris, A., Sweetman, O., Casey, R., \& Raffe, D. (2013). An evaluation of the HEAR and DARE supplementary admission routes to higher education. Dublin: Irish Universities Association.

Clancy, P., \& Goastellec, G. (2007). Exploring access and equity in higher education: Policy and performance in a comparative perspective. Higher Education Quarterly, 61(2), 136-154.

Clancy, P., \& Wall, J. (2000). Social background of higher education entrants. Dublin: Higher Education Authority.

CSO. (2016). Census of population 2016: Profile 4, households and families. Dublin: Central Statistics Office.

Donnelly, M., \& Evans, C. (2018). A "home-international” comparative analysis of widening participation in UK higher education. Higher Education. Advanced online publication. Retrieved from link.springer.com/ article/10.1007/s10734-018-0260-3

Ehrenberg, R. G., \& Sherman, D. R. (1984). Optimal financial aid policies for a selective university. The Journal of Human Resources, 19(2), 202-230.

HEA. (2015). National plan for equity of access to higher education 2015-2019. Dublin: The Higher Education Authority.

Heil, S., Reisel, L., \& Attewell, P. (2014). College selectivity and degree completion. American Educational Research Journal, 51(5), 913-935.
Hussain, I., McNally, S., \& Telhaj, S. (2009). University quality and graduate wages in the UK (IZA Discussion Paper no 4043). London: London School of Economics.

Jerrim, J., Chmielewski, A. K., \& Parker, P. (2015). Socioeconomic inequality in access to high-status colleges: A cross-country comparison. Research in Social Stratification and Mobility, 42, 20-32.

Jones, R., \& Thomas, L. (2005). The 2003 UK Government Higher Education White Paper: A critical assessment of its implications for the access and widening participation agenda. Journal of Education Policy, 20(5), 615-630.

Karabel, J. (2005). The chosen: The hidden history of admission and exclusion at Harvard, Yale, and Princeton. Boston, MA: Houghton Mifflin.

Kelly, E., O'Connell, P. J., \& Smyth, E. (2010). The economic returns to field of study and competencies among higher education graduates in Ireland. Economics of Education Review, 29, 650-657.

McCoy, S., \& Smyth, E. (2011). Higher education expansion and differentiation in the Republic of Ireland. Higher Education, 61, 243-260.

McDonough, P. M. (1997). Choosing colleges: How social class and schools structure opportunity. Albany, NY: New York Press.

Mountford-Zimdars, A., Moore, J., \& Graham, J. (2016). Is contextualised admission the answer to the access challenge? Perspectives: Policy and Practice in Higher Education, 20(4), 143-150.

Murphy, P. (2009). Higher education access/foundation courses: A research report. Dublin: HEA, IOTI \& IUA.

Nic Fhlannchadha, S. (2017). DARE HEAR facts and figures report 2017. Summary. Dublin: Irish Universities Association.

O’Sullivan, K., Robson, J., \& Winters, N. (2018). "I feel like I have a disadvantage": How socio-economically disadvantaged students make the decision to study at a prestigious university. Studies in Higher Education. Advanced online publication. https://doi.org/ 10.1080/03075079.2018.1460591

Office of National Statistics. (2017). Families and households. London: ONS.

Ozga, J. (2000). Policy research in educational settings: contested terrain. Buckingham: Open University Press.

Robertson, D., \& Hillman, J. (1997). Widening participation in higher education for students from lower socio-economic groups and students with disabilities. In R. Dearing (Ed.), Higher education in the learning society (pp. 59-74). London: The National Committee of Inquiry into Higher Education, HMSO.

Sanders, L., \& Daly, A. (2013). Building a successful foundation? The role of foundation year courses in preparing students for their degree. Widening Participation and Lifelong Learning, 15, 42-56.

Sanders, L., Daly, A., \& Fitzgerald, K. (2016). Predicting retention, understanding attrition: A prospective study 
of foundation year students. Widening Participation and Lifelong Learning, 18(2), 50-83.

Schwartz, S. (2004). Fair admissions to higher education: Recommendations for good practice. The 'Schwartz Report' (Report of the Admissions to Higher Education Steering Group). Nottingham: DfES.

Share, M., \& Carroll, C. (2013). Ripples of hope: The family and community impact of Trinity College Dublin access graduates. Dublin: Trinity College Dublin.

Smith, J. A., Flowers, P., \& Larkin, M. (2009). Interpretative phenomenological analysis: Theory, method and research. London: SAGE Publications.

Stevens, M. L. (2007). Creating a class: College admissions and the education of elites. Cambridge, MA: Harvard University Press.

Sundorph, E., Vasilev, D., \& Coiffait, L. (2017). Joining the elite: How top universities can enhance social mobility. London: Reform.

Thomsen, J. P. (2018). Test-based admission to selective universities: A lever for first-generation students or a safety net for the professional classes? Sociology, 52(2), 333-350.

Thomas, L. (2011). Do pre-entry interventions such as 'Aimhigher' Impact on student retention and success? A review of the literature. Higher Education Quarterly, 65(3), 230-250.

UCAS. (2017). Foundation degree course search. Digital UCAS. Retrieved from digital.ucas.com/search

Weber, M. (1978). Economy and society: An outline of interpretive sociology. Berkeley, CA: University of California Press.

Zimdars, A. (2010). Fairness and undergraduate admission: A qualitative exploration of admissions choices at the University of Oxford. Oxford Review of Education, 36(3), 307-323.

Zimdars, A., Sullivan, A., \& Heath, A. (2009). Elite higher education admissions in the arts and sciences: Is cultural capital the key? Sociology, 43(4), 648-666.

\section{About the Authors}

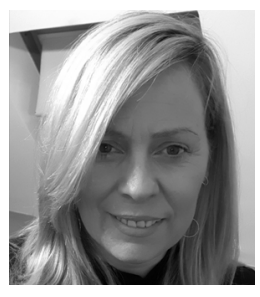

Katriona O'Sullivan is Lecturer at Maynooth University. Her research interests include widening participation in higher education and the social mobility of socio-economically disadvantaged groups. She has a particular interest in alternative entry routes to higher education and uses a variety of research methods, designs and data to explore these themes.

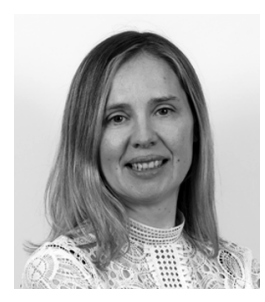

Delma Byrne is Lecturer in Social Stratification and Sociology of Education at Maynooth University. Her work explores the mechanisms through which inequality is (re)produced within education settings, including Higher Education, and the effects of educational inequality on youth transitions.

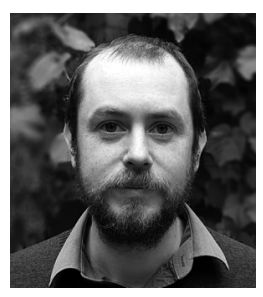

James Robson is a Research Fellow and Convenor of the MSc in Higher Education at the Department of Education, Oxford University. He researches issues around access and widening participation in Higher Education, with a particular focus on how inequalities are manifested in skills development and labour market outcomes.

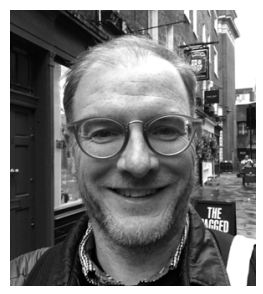

Niall Winters (PhD) is an Associate Professor of Learning and New Technologies at the Department of Education, University of Oxford where he is also a Fellow of Kellogg College. He researches the development of technologies for marginalised communities. 